Int. J. Morphol.,

33(4):1436-1440, 2015.

\title{
Ultrastructure of Fetal Mice Hepatocytes Exposed in Utero to Diazepam
}

\author{
Ultraestructura de Hepatocitos Fetales de Ratón Expuestos in Utero a Diazepam
}

María Cristina Márquez-Orozco*; Graciela de la Fuente-Juárez* \& Amalia Márquez-Orozco*

MÁRQUEZ-OROZCO, M. C.; DE LA FUENTE-JUÁREZ, G. \& MÁRQUEZ-OROZCO, A. Ultrastructure of fetal mice hepatocytes exposed in utero to diazepam. Int. J. Morphol., 33(4):1436-1440, 2015.

SUMMARY: Previous research has shown that fetal mice hepatic cells from females treated with diazepam (Valium) during pregnancy depict cytoplasmic and nuclear modifications when observed with photonic microscope. The purpose of this work is to investigate if diazepam administered subcutaneously (SC) to pregnant mice females induces ultraestructural alterations in the cytoplasmic organelles and nucleus to fetal hepatocytes. Transmission electron microscopy observations of fetal hepatocytes from pregnant females treated with a single daily dose of diazepam $2.7 \mathrm{mg} / \mathrm{kg} / \mathrm{bw} / \mathrm{SC}$ administered from $6^{\text {th }}$ to $15^{\text {th }}$ days of gestation revealed that they frequently presented disorganized and dilated rough endoplasmic reticulum cisterns, membranous elements, abundant Golgi complex and glycogen granules, around large vacuoles. The voluminous nucleus shows atypical distribution of chromatin. These alterations could modify the hepatocyte's physiology and probably persist after birth.

KEY WORDS: Benzodiazepines; Diazepam; Fetal hepatocytes; Ultrastructure.

\section{INTRODUCTION}

Diazepam (DZ) is a minor tranquilizer drug that is used as anticonvulsant, sedative, hypnotic with amnestic effects (Feldman et al., 1997).

Diazepam crosses the placental barrier in humans and mice. Levels of diazepam in the fetal blood are higher than in the maternal blood. It accumulates in the liver and other fetal tissues and is eliminated slowly through the urinary tract. It produces respiratory and neurological depression, hypothermia, hyporeflexia and hypotony in newborns from mothers treated with diazepam during labor (Mandelli et al., 1975). DZ is used in women with various psychiatric disorders, taken during pregnancy either intentionally or by accident especially in the first trimester it can induced adverse effects on the newborn (Harding \& Timken, 2014). DZ is used also as a drug of abuse (Cole \& Chiarello, 1990).

A study on 36 mothers (37 infants), who regularly took benzodiazepines (diazepam or oxazepam) during pregnancy, revealed seven cases of infants with dysmorphism, intrauterine malformations and extrauterine growth restriction, central nervous system dysfunction, (such as psychomotor retardation and autistic traits), and neonatal abstinence syndrome. At lower benzodiazepine concentrations the infants presented hypotonia, hyperexcitability, and delayed psychomotor development and, later on, hyperactivity, perceptual disorders and learning disabilities (Laegried et al., 1989, 1990).

Studies in our laboratory, using mice fetuses (CD-1 strain), treated in Utero with diazepam $(2.7 \mathrm{mg} / \mathrm{kg}$ administered subcutaneously, SC) from the $6^{\text {th }}$ to $15^{\text {th }}$ day of gestation have shown histological changes in the placenta (Márquez-Orozco et al., 2014), cerebral cortex (MárquezOrozco et al., 1992) and cerebellar cortex (Andrada-Martínez et al., 1993). Diazepam also induces ultrastructural changes in the heart (Márquez-Orozco et al., 1983) and retina (Márquez-Orozco et al., 1992). The aim of this study was to determine whether diazepam, which attaches to the fetal hepatocytes, produces ultrastructural changes in the cytoplasmic organelles and nucleus.

\section{MATERIAL AND METHOD}

Virgin female CD-1 strain mice, 2 months old, were mated with males of the same age. One male was housed 
in the same cage with three females between 05:00 to 05:30 $h$. The presence of vaginal plugs was taken as the start of gestation and such animals were randomly distributed into two groups, the (diazepam group DZ) injected from days 6 to 15 of gestation, with either single daily doses of diazepam $(2.7 \mathrm{mg} / \mathrm{kg} / \mathrm{bw} / \mathrm{SC})$ or an equivalent volume of saline solution (control group. C). Animals were maintained in a pathogen free environment with food and water ad libitum, with light/dark cycles of $12 / 12 \mathrm{~h}$ starting at 07:00 $\mathrm{h}$. On the $16^{\text {th }}$ day, animals were decapitated, fetuses were perfused intracardially with a mixture of paraformaldehyde (1\%), glutaraldehyde $(2.5 \%)$ and cacodylate $(0.16 \mathrm{M})$, buffered at $\mathrm{pH} 7.0$. The liver was removed and post-fixed in $\mathrm{O}_{\mathrm{s}} \mathrm{O}_{4}(1 \%)$, embedded in epoxy resin, sectioned and stained with lead citrate and uranyl acetate for electron microscopy and observed under a transmission electron microscope Zeiss M-10.

\section{RESULTS}

The liver of DZ treated mice fetuses revealed hepatocytes with large round nuclei; the membrane unit was easily distinguished, heterochromatin formed clumps that frequently adhered to the membrane or appeared dispersed in the karyolymph, which was slightly electron dense. The interchromatin granules were scarce and stained poorly. Large vacuoles were observed. The fetal hepatocytes of the $\mathrm{C}$ group showed normal appearance (Figs. 1 and 2). The rough endoplasmic reticulum showed cisterns, that, instead of being parallel, like those observed in the $\mathrm{C}$ group (Fig. 3) were distributed irregularly in the cytoplasm; they were diverse in size with fewer ribosomes attached to their membranes than

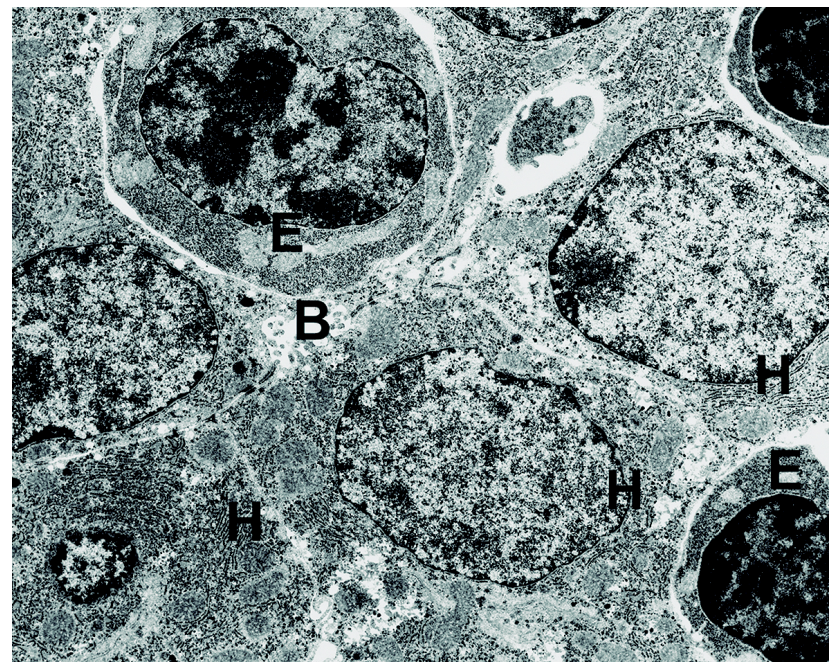

Fig. 1. Transmission electron micrograph showing control mouse fetal liver of the demonstrating the normal appearance of hepatocyte (H), erythroblasts (E) and bile canaliculi (B). X12, 100.

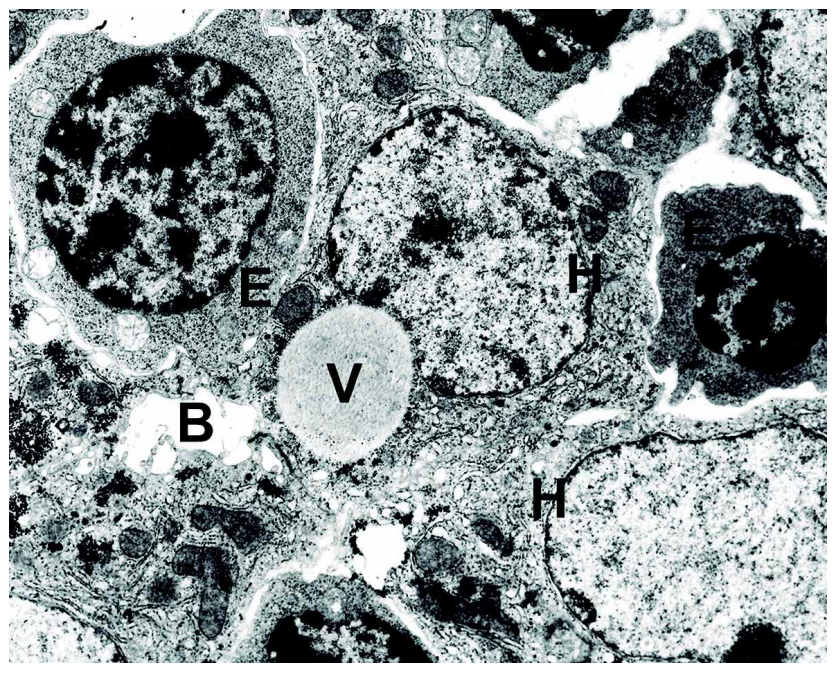

Fig. 2. Transmission electron micrograph showing DZ mouse fetal liver demonstrating the abnormal appearance of hepatocytes $(\mathrm{H})$ with a large vacuole (V), erythroblasts (E) and bile canaliculi (B). $\mathrm{X} 12,100$.

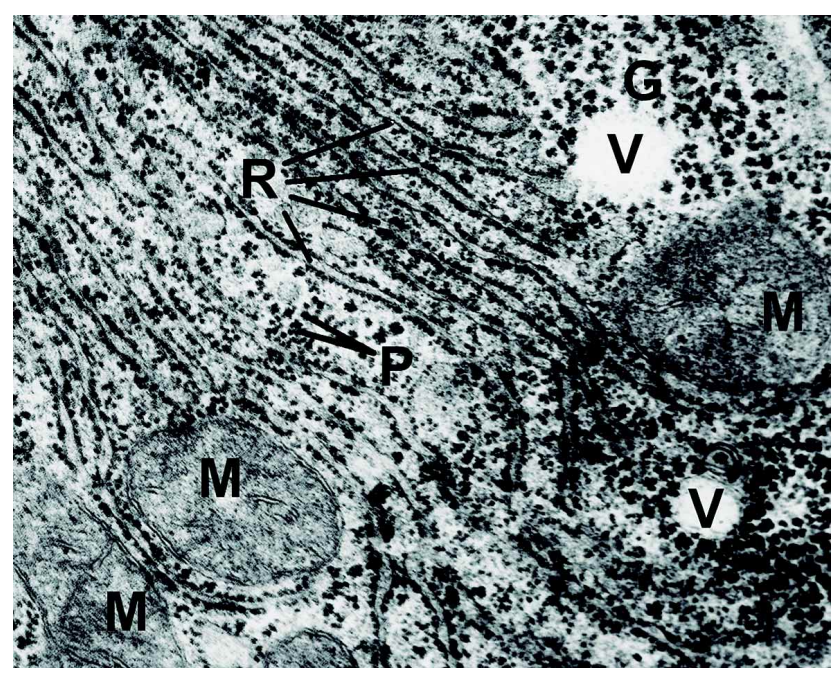

Fig. 3. Transmission electron micrograph showing a portion of cytoplasmic hepatocyte of control mouse fetus demonstrating the relationship of the normal rough endoplasmic reticulum surfaced (R) with ribosomes, mitochondria $(\mathrm{M})$, polyribosomes $(\mathrm{P})$, vacuoles (V) and glycogen grains (G). X61, 320.

those observed in the controls. Numerous sets of polyribosomes were also identified (Figs. 3 and 4). Membranous elements and multiple vesicle bodies of different sizes and shapes could be observed, some of them near the Golgi complex (Fig. 5). Among the cytoplasmic organelles, numerous glycogen granules were observed, mainly surrounding large vacuoles containing a low electron dense material and limited by a welldefined membrane (Fig. 6). Occasionally, sets of vacuoles, separated only by their membrane or some glycogen granules, could be detected in the interior; they were surrounded by low contrast granules intermingled with others that were highly 


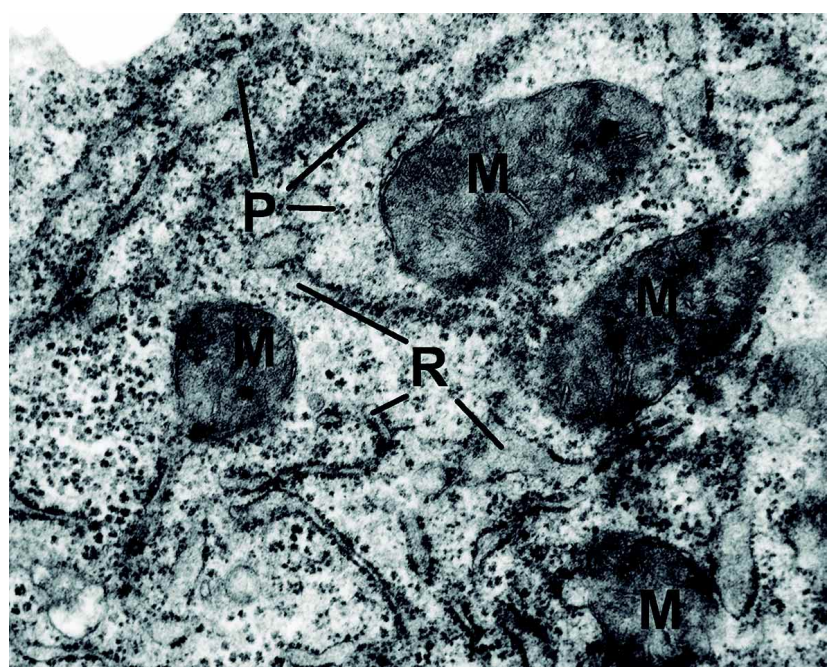

Fig. 4. Transmission electron micrograph showing a portion of cytoplasmic hepatocyte of diazepam-treated mouse fetus, demonstrating disorganized rough endoplasmic reticulum surface $(\mathrm{R})$ with ribosomes, polyribosomes (P) and mitochondria (M). X61, 320.

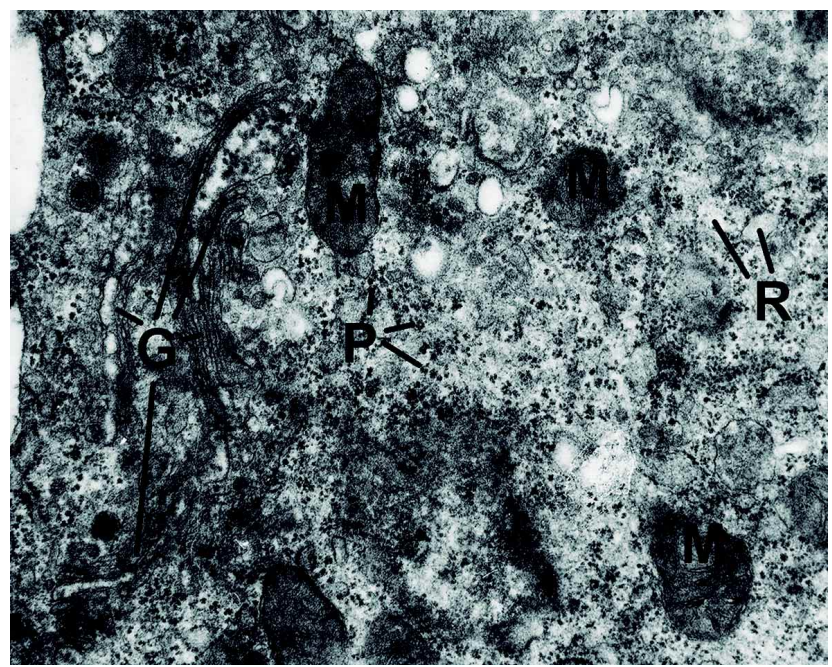

Fig. 5. Transmission electron micrograph showing a portion of cytoplasmic hepatocyte of diazepam-treated mouse fetus, demonstrating abundant Golgi complex (C), disorganized rough endoplasmic reticulum surface $(\mathrm{R})$ with ribosomes, polyribosomes $(\mathrm{P})$ and mitochondria $(\mathrm{M})$. X31, 700.

electron dense (Fig. 7). The latter were easily identified among abnormal the cisterns of the rough endoplasmic reticulum, mitochondria, polyribosomes, larges lysosomes and degenerated cytoplasmic (Fig. 8). Mitochondria were numerous in the fetal hepatocytes of the DZ group and their morphology was similar to that observed in the controls (Figs. 4 and 5). The biliary canaliculi had less microvillus in the experimental group and the erythroblasts were atypically condensed, so that the heterochromatin appeared to be more abundant (Figs. 1 and 2).

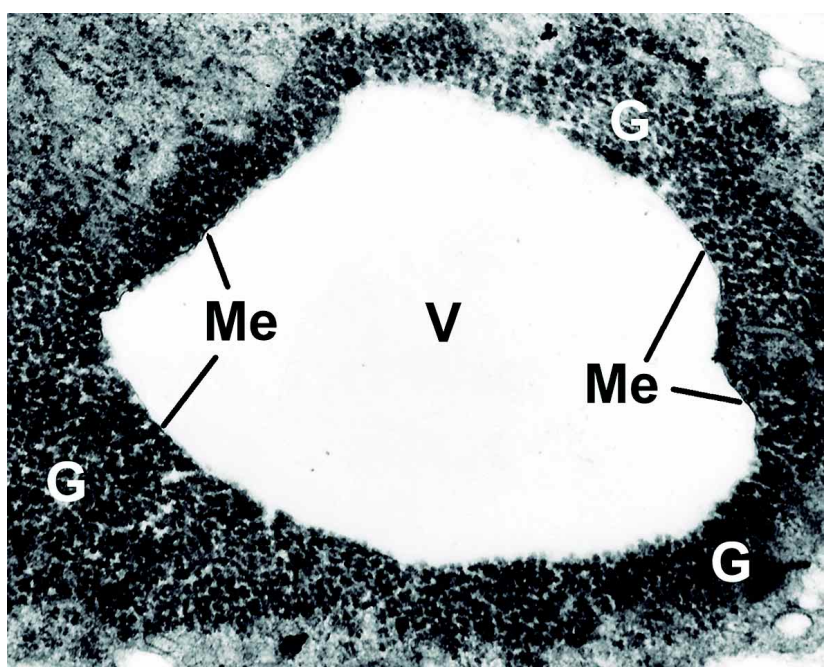

Fig. 6. Transmission electron micrograph showing glycogen grains (G) around a large vacuole (V) limited by a well-defined membrane (Me) in the hepatocyte of a diazepam-treated mouse fetus. X61, 320.

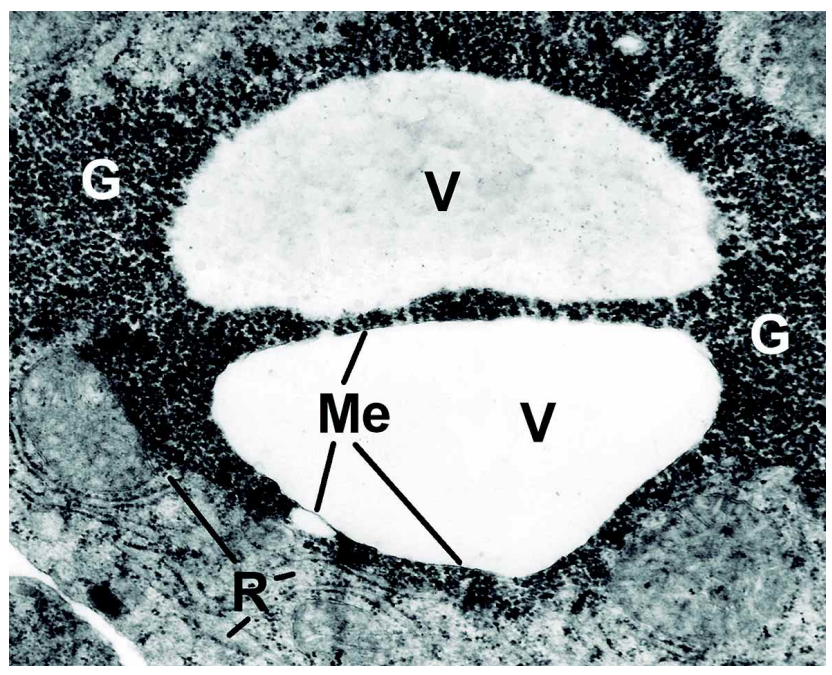

Fig. 7. Transmission electron micrograph showing glycogen grains (G) around a larges vacuoles (V) limited by a well-defined membrane (Me), abnormal rough endoplasmic reticulum (R) surface with ribosomes, in a hepatocyte of a diazepam-treated mouse fetus. X44, 520 .

\section{DISCUSSION}

The appearance of the chromatin in the fetal hepatocytes of the DZ group could be due to chromatin ruptures, similarly to those observed by (Stenchever \& Frankel, 1969; Stenchever et al., 1970) in leukocytes of patients treated with diazepam for periods between 0.5 to 35 months and in human fibroblasts cultured with diazepam, from patients and fetuses. These events could affect cellular 


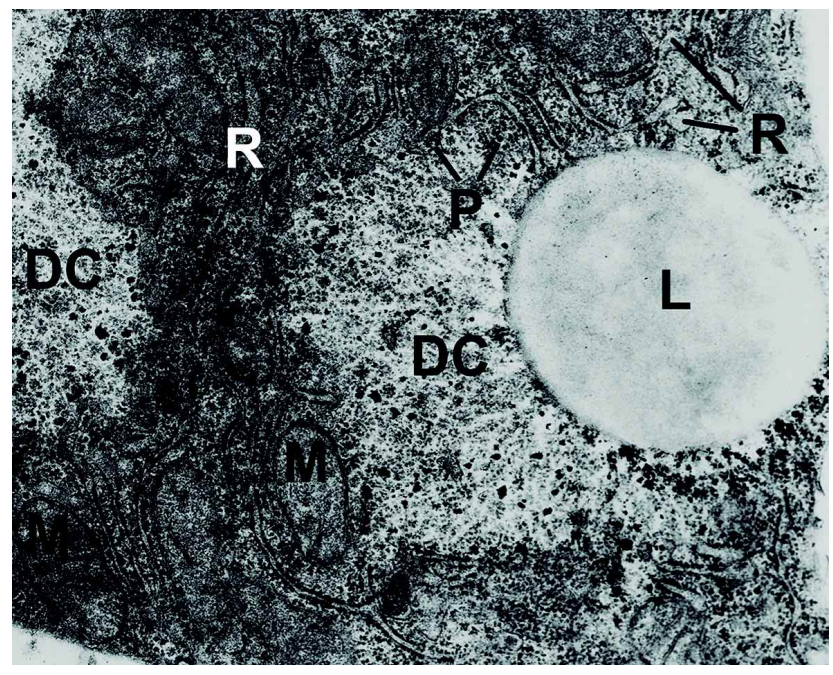

Fig. 8. Transmission electron micrograph showing a degenerated cytoplasmic (DC) in a hepatocyte with abnormal rough endoplasmic reticulum surface $(\mathrm{R})$ with ribosomes, mitochondria $(\mathrm{M})$ and large lysosome (L) from a diazepam-treated mouse fetus. X38, 220.

division by interfering with the separation of the centrioles, as has been observed in cell cultures of the JOK-1 strain (Andersson et al., 1981). And other evidence for the toxicity of diazepam can be found in its inhibitory effects on the second division during meiosis, thereby producing cell degeneration. This effect on chromatin and cellular reproduction could, in turn, disorganize the cytoplasmic organelles such as the rough endoplasmic reticulum. The latter, besides being distended, has fewer ribosomes adhering to the membrane and shows, instead, numerous polyribosomes, a morphological manifestation of altered protein synthesis; this has been demonstrated in the heavy chain myosin of myoblasts in chicken embryos inhibited by diazepam (Bandman et al., 1978; Renehan \& Kulikow, 1981). Changes in the rough endoplasmic reticulum are observed in cardiac tissue, and in the retina, with increasing amounts of cisterns and vesicles in the Golgi complex, indicating an effect of diazepam on the tissues in which it accumulates. These effects could be due to nuclear changes or to the direct action of the drug and its metabolites on the cytoplasmic organelles, which would respond by producing lysosomes or forming large vacuoles similar to those described in the hepatocytes, myoblasts, and by synthesizing and depositing large amounts of glycogen granules around the enlarged vacuoles (Márquez-Orozco et al., 1983; Márquez-Orozco et al., 1992). This latter action would prevent degeneration of the fetal cells, which still lack the specific enzymatic mechanisms for deintoxication, and, in some instances, are not able to metabolize toxic substances. Another explanation for the atypically distributed chromatin could be that the peripheral benzodiazepine receptors in the liver, kidney, heart, lung, placenta and brain (Bosman et al., 1980; Marangos et al., 1982; Aaltonen et al., 1983), bind to benzodiazepines in the nucleus, or in the nuclear membrane and mitochondria, which could enhance the toxic effects of the drug by forming intracellular macromolecular complexes that could modify directly the metabolism of nucleic acids, $\mathrm{Ca}^{2}+$ and secondarily that of the cytoplasmic organelles. In human fibroblasts cultured with diazepam, distension of the rough endoplasmic reticulum, membranous elements electrondense granules, increase of cisterns and vesicles in the Golgi complexes, delay in culture growth, and diminution in collagen synthesis (Breen \& Stenchever, 1970) coincide with those occurring in hepatocytes suggesting that, if the change was induced at the nuclear level, they might persist postnatal (Moggs \& Orphanides, 2004). In fact, postnatal effects on behavior have been observed in diazepam treated rats (Kellogg et al., 1983; Kellogg, 1991; Simmons et al., 1984), these physiological manifestations must evidently have a morphological substrate.

Adult mice prenatally treated with diazepam, present histological changes in the cerebral cortex (Márquez-Orozco et al., 1992), and cerebellar cortex (Márquez-Orozco et al., 1988), giving support to the suggestion that the changes occurring during intrauterine life persist in newborn and adult mice.

MÁRQUEZ-OROZCO, M. C.; DE LA FUENTE-JUÁREZ, G. \& MÁRQUEZ-OROZCO, A. Ultraestructura de hepatocitos fetales de ratón expuestos in utero a diazepam. Int. J. Morphol., 33(4):1436-1440, 2015.

RESUMEN: Estudios previos muestran que las células hepáticas de fetos de ratón, de hembras tratadas con diazepam (Valium) durante la gestación, presentan modificaciones citoplásmicas y nucleares que se pueden observar con el microscopio fotónico, por lo que el propósito de este trabajo es determinar si el diazepam administrado por vía subcutánea (SC) a hembras gestantes de ratón, induce alteraciones ultraestructurales de los organelos citoplásmicos y del núcleo de los hepatocitos fetales. En los fetos de ratón del grupo experimental de hembras gestantes, tratadas con dosis únicas diarias de $2,7 \mathrm{mg} / \mathrm{kg}$ de peso corporal administradas por vía SC del $6^{\circ}$ al $15^{\circ}$ día de la gestación, se observó con el microscopio electrónico de transmisión que los hepatocitos fetales presentaban con frecuencia retículo endoplásmico rugoso desorganizado, con cisternas dilatadas; había elementos membranosos y complejo de Golgi abundante, al igual que gránulos de glucógeno que rodeaban a grandes vacuolas. Los núcleos eran voluminosos, con la cromatina distribuida atípicamente. Estas alteraciones podrían modificar la fisiología de los hepatocitos y probablemente persistan después del nacimiento.

PALABRAS CLAVE: Benzodiazepinas; Diazepam; Hepatocitos fetales; Ultraestructura. 


\section{REFERENCES}

Andrada-Martínez, R.; Márquez-Orozco, M. C. \& Márquez-Orozco, A. Cerebellar histological changes produced by diazepam. Proc. West. Pharmacol. Soc., 36:219-25, 1993.

Aaltonen, L.; Erkkola, R. \& Kanto, J. Benzodiazepine receptors in the human fetus. Biol. Neonate, 44(1):54-7, 1983.

Andersson, L. C.; Letho, V. P.; Stenman, S.; Bradley, R. A. \& Virtanen, L. Diazepam induces mitotic arrest at prometaphase by inhibiting centriolar separation. Nature, 291(5812):247-8, 1981.

Bandman, E.; Walker, C. R. \& Strohman, R. C. Diazepam inhibits myoblast fusion and expression of muscle specific protein synthesis. Science, 200(4341):559-61, 1978.

Bosmann, H. B.; Penney, D. P.; Case, K. R. \& Averill, K. Diazepam receptor: specific nuclear binding of $[3 \mathrm{H}]$ flunitrazepam. Proc. Natl. Acad. Sci. USA, 77(2):1195-8, 1980.

Breen, P. C. \& Stenchever, M. A. Some effects of diazepam on the fine structure of human fibroblasts in tissue culture.e. Am. J. Obstet. Gynecol., 108(4):520-7, 1970.

Cole, J. O. \& Chiarello, R. J. The benzodiazepines as drugs of abuse. J. Psychiatr. Res., 24(Suppl. 2):135-44, 1990.

Feldman, R. S.; Meyer, J. S. \& Quenzer, L. F. Sedative-hypnotic and anxiolytic drugs. In: Principles of neuropsychopharmacology. Sunderland, Sinauer Associates Inc., 1997.

Harding, J. H. \& Timko, J. V. The use of psychotropic medications during pregnancy and lactation. Glob. Libr. Women's Med., 2008. Disponible en: https://www.glowm.com/search_results?p= glow m.c ml/s e a r ch \& que ry $=$ The + U s e +of + Psychotropic+Medications+ During+Pregnancy+\%28and+ Lactation\&search $=1$

Kellogg, C. K. Postnatal effects of prenatal exposure to psychoactive drugs. Pre Peri Natal Psychol., 5:233-51, 1991.

Kellogg, C. K.; Chrisholm, J.; Simmons, R. D.; Ison, F. R. \& Miller, R. K. Neural and behavioral consequences of prenatal exposure to diazepam. Monogr. Neural Sci., 9:119-20, 1983.

Laegreid, L.; Olegard, R.; Walström, J. \& Conradi, N. Teratogenic effects of benzodiazepine use during pregnancy. J. Pediatr., 114(1)126-31, 1989.

Laegreid, L.; Olegard, R.; Conradi, N.; Hagberg, G.; Wahlström, J. \& Abrahamsson, L. Congenital malformations and maternal consumption of benzodiazepines: a case-control study. Dev. Med. Child. Neurol., 32(5):432-41, 1990.

Mandelli, M.; Morselli, P. L.; Nordio, S.; Pardi, G.; Principi, N.; Sereni, F. \& Tognoni, G. Placental transfer to diazepam and its disposition in the newborn. Clin. Pharmacol. Ther, 17(5):564-72, 1975.

Marangos, P. J.; Patel, J.; Boulenger, J. P. \& Clark-Rosenberg, R. Characterization of peripheral-type Characterization of peripheral- type benzodiazepine binding sites in brain using [3H]Ro 5-4864. Mol. Pharmacol., 22(1):26-32, 1982.

Márquez-Orozco, A.; Márquez-Orozco, M. C. \& Alcántara-Ortigoza, M. A. Effects of prenatal administration of diazepam on the cerebral cortex of adult mice. Proc. West. Pharmacol. Soc., 35:47-52, 1992.

Márquez-Orozco, M. C.; Gazca-Ramírez, M. V. \& Márquez-Orozco, A. Ultrastructural alterations of fetal mice heart produced by treatment with diazepam during gestation. Proc. West. Pharmacol. Soc., 26:83-4, 1983

Márquez-Orozco, M. C.; Márquez-Orozco, A. \& Escobar, A. Diazepam induced long term delay in the migration of external granular layer of the cerebellum: an experimental study in the mouse. Bol. Estud. Med. Biol., 36(1-4):19-24, 1988.

Márquez-Orozco, M. C.; Gazca-Ramírez, M. V.; de la Fuente-Juárez, G. \& Márquez-Orozco, A. Morphological alterations in mouse placenta induced by diazepam. Int. J. Morphol., 32(2):426-31, 2014.

Márquez-Orozco, M. C.; Márquez-Orozco, A. \& Gazca-Ramírez, M. V. Ultrastructural changes in photoreceptors and retinal layers of the mouse fetus exposed to diazepam. Proc. West. Pharmacol. Soc., 35:43-6, 1992

Moggs, J. G. \& Orphanides, G. The role of chromatin in molecular mechanisms of toxicity. Toxicol. Sci., 80(2):218-24, 2004.

Renehan, W. E. \& Kulikowski, L. R. R. Abnormal heart development in valium-treated embryo. Biophys. J., 33:244a, 1981.

Simmons, R. D.; Miller, R. K. \& Kellogg, C. K. Prenatal exposure to diazepam alters central and peripheral responses to stress in adult rat offspring. Brain Res., 307(1-2):39-46, 1984.

Stenchever, M. A. \& Frankel, R. B. Some effects of diazepam in human cells in vitro. Amer. J. Obstet. Gynecol., 103(6):836-42, 1969.

Stenchever, M. A.; Frankel, R. S. \& Jarvis, J. A. Effect of diazepam on chromosomes of human leukocytes in vivo. Am. J. Obstet. Gynecol., 107(3):456-60, 1970.

Correspondence to:

María Cristina Márquez Orozco

Departamento de Embriología

Facultad de Medicina

Universidad Nacional Autónoma de México (UNAM)

Mexico D.F. 04510

MEXICO

Email: cmarquezor@gmail.com

Received: 26-06-2015

Accepted: 20-08-2015 